\title{
MULTIPLE POSITIVE SOLUTIONS FOR NONLOCAL BOUNDARY VALUE PROBLEMS WITH $p$-LAPLACIAN OPERATOR
}

\author{
SHENG-PING WANG
}

Abstract. The main goal of this article is to establish an existence result for the following multipoint boundary value problem:

$$
\begin{gathered}
\left(\phi_{p}\left(u^{\prime}\right)\right)^{\prime}+q(t) f\left(t, u(t), u^{\prime}(t)\right)=0, t \in(0,1), \\
u(0)=\sum_{i=1}^{m-2} a_{i} u\left(\xi_{i}\right), \phi_{p}\left(u^{\prime}(1)\right)=\sum_{i=1}^{m-2} b_{i} \phi_{p}\left(u^{\prime}\left(\xi_{i}\right)\right),
\end{gathered}
$$

where $\phi_{p}(s)=|s|^{p-2} s, p>1$, and $0<\xi_{1}<\xi_{2}<\cdots<\xi_{m-2}<1$. By means of fixed point theorem due to Avery and Peterson, we study the existence of at least three positive solutions to our problem and get some information about these solutions under some sufficient conditions posed.

Mathematics subject classification (2010): 34B10, 34B15, 34B18.

Keywords and phrases: Positive solution, multi-point boundary value problem, $p$-Laplacian, AveryPeterson fixed-point theorem, completely continuous.

\section{REFERENCES}

[1] M. Moshins Ky, Sobre los problemas de condiciones a la frontiera en una dimension de caracteristicas discontinuas, Bol. Soc. Mat. Mexicana, vol. 7, 10-25, 1950.

[2] V. A. IL'IN AND E. I. MOISEEV, Nonlocal boundary value problem of the second kind for a SturmLiouville operator, Diff. Equ., vol. 23, 979-987, 1987.

[3] G. L. Karakostas And P. CH. Tsamatos, Positive solutions of a boundary value problem for second order ordinary differential equations, Electron. J. of Diff. Equ., vol. 49, 1-9, 2000.

[4] R. MA, D. CAO, Positive solutions to an m-point boundary value problem, Appl. Math. J. Chinese Univ. Ser. B., vol. 17, 24-30, 2002.

[5] C. P. GUPTA AND S. I. TROFIMCHUK, A sharper condition for the solvability of a three-point second order boundary value problem, J. Math. Anal. Appl., vol. 205, 586-597, 1997.

[6] R. MA AND H. WANG, Positive solutions of a nonlinear three-point boundary value problems, J. Math. Anal. Appl., vol. 279, 216-227, 2003.

[7] R. MA, Positive solutions of nonlinear m-point boundary value problem, An International J. Comput. Math. Appl., vol. 42, 755-765, 2001.

[8] H. B. ThOMPSON AND C. TISDELL, Three-point boundary value problems for second-order, ordinary, differential equations, Math. Comput. Modelling, vol. 34, 311-318, 2001.

[9] Q. YAO, On the positive solutions of a second-order three-point boundary value problem with Carathéodory function, Southeast Asian Bull. Math., vol. 28, 577-585, 2004.

[10] Q. YAO, Successive iteration and positive solution for nonlinear second-order three-point boundary value problems, An International J. Comput. Math. Appl., vol. 50, 433-444, 2005.

[11] R. A. KHAN AND J. R. L. WEBB, Existence of at least three solutions of a second-order three-point boundary value problem, Nonlinear Anal., vol. 64, 1356-1366, 2006.

[12] S. P. Wang And L. Y. Ts AI, Existence Results of Three-Point Boundary Value Problems for Secondorder Ordinary Differential Equations, Boundary Value Problems, vol. 2011, Article ID 901796, 18 pages, 2011. 
[13] Y. Sun, L. LiU, J. ZHANG AND R. P. AgARWAL, Positive solutions of singular three-point boundary value problems for second-order differential equations, J. Comput. Appl. Math., vol. 230, 738-750, 2009.

[14] Z. BAI AND Z. DU, Positive solutions for some second-order four-point boundary value problems, J. Math. Anal. Appl., vol. 330, 34-50, 2007.

[15] M. FENG AND W. GE, Positive solutions for a class of m-point singular boundary value problems, Math. Comput. Modelling, vol. 46, 375-383, 2007.

[16] H. LÜ, D. O'REGAN AND C. ZHONG, Multiple positive solutions for the one-dimensional singular p-Laplacian, Appl. Math. Computation, vol. 133, 407-422, 2002.

[17] Y. WANG AND C. HoU, Existence of multiple positive solutions for one-dimensional p-Laplacian, J. Math. Anal. Appl., vol. 315, 144-153, 2006.

[18] Y. WANG AND W. GE, Positive solutions for multipoint boundary value problems with a onedimensional p-Laplacian, Nonlinear Anal., vol. 66, 1246-1256, 2007.

[19] H. FENG, W. GE AND M. JIANG, Multiple positive solutions for $m$-point boundary-value problems with a one-dimensional p-Laplician, Nonlinear Anal., vol. 68, 2269-2279, 2008.

[20] D. BAI AND H. FENG, Three positive solutions for $m$-point boundary-value problems with onedimensional p-Laplician, Electronic J. Diff. Equ., vol. 2011, 1-10, 2011.

[21] D. MA, Y. TIAN AND W. GE, Existence Theorems of Positive Solutions for a Fourth-order three-point boundary value problem, Taiwanese J. Math., vol. 10, no. 6, 1557-1573, 2006.

[22] R. I. AVERy And A. C. Peterson, Three fixed points of nonlinear operators on ordered Banach spaces, Comput. Math. Appl., vol. 42, 313-322, 2001.

[23] R. I. AVERY, A generalization of the Leggett-Williams fixed point theorem, MSR Hot-Line, vol. 3, no. 7, 9-14, 1999. 